\title{
Cholesterol Levels and Nutritional Composition of Commercial Layers Eggs Fed Diets with Different Vegetable Oils
}

\section{mAuthor(s)}

Faitarone $A B G$

Garcia EA ${ }^{2}$

Roça $\mathrm{R}$ de $\mathrm{O}^{3}$

Ricardo $\mathrm{H}_{\text {de }} \mathrm{A}^{4}$

Andrade $\mathrm{E} \mathrm{N} \mathrm{de}^{5}$

Pelícia $\mathrm{K}^{6}$

Vercese $\mathrm{F}^{4}$

Ph.D., post-doctoral studies at Department of Agro-industrial Management and Technology-FCA/UNESP-Botucatu e-mail: abiazinha2003@yahoo.com.br

2 Professor, Department of Animal Production - FMVZ/ UNESP-Botucatu

3 Professor, Department of Agro-industrial Management and Technology - FCA UNESP-Botucatu

${ }^{4}$ Ph.D. student in Animal Science - FMVZ/ UNESP-Botucatu

Department of Agro-industrial Management and Technology - FCA UNESP-Botucatu

6 Professor, Department of Animal Science, UNIFENAS - Alfenas/MG

\section{Mail Adress}

Corresponding author e-mail address

Ana Beatriz Garcia Faitarone -

Departamento de Gestão e Tecnologia Agroindustrial - F.C.A - UNESP - Campus de Botucatu - Fazenda Lageado Botucatu - SP - CEP:18603-190

Caixa Postal: 237

email: abiazinha2003@yahoo.com.br

\section{"Keywords}

Fatty acids, cholesterol, nutritional composition, vegetable oils, commercial eggs.

\section{ABSTRACT}

This experiment aimed at evaluating the effects of the supplementation of different vegetable oils at different levels to the diet of commercial layers on egg cholesterol levels and nutritional composition (proteins, total solids, lipids, and ashes) for 112 days. Birds were distributed according to a completely randomized experimental design with 10 treatments ( $\mathrm{T} 1$ - control; $\mathrm{T} 2$ - inclusion of $2.5 \%$ rapeseed oil; T3 - inclusion of $2.5 \%$ canola oil; T4 - inclusion of $2.5 \%$ soybean oil; T5 - inclusion of 5\% rapeseed oil; T6 - inclusion of 5\% canola oil; T7 - inclusion of $5 \%$ soybean oil; T8 - inclusion of $2.5 \%$ rapeseed oil $+2.5 \%$ soybean oil; T9 - inclusion $2.5 \%$ canola oil $+2.5 \%$ soybean oil; $\mathrm{T} 10$ - inclusion of $2.5 \%$ rapeseed oil $+2.5 \%$ canola oil) of six replicates of eight birds each, totaling 480 birds. Yolk cholesterol levels and nutritional composition were determined on days 20,60 and 112 days of the experimental period. Data obtained during the experimental period were submitted to analysis of variance. Egg yolks produced by layer fed oils presented lower cholesterol levels after 20 days of inclusion in the experimental diets. On days 60 and 112, cholesterol levels were higher. It was concluded that supplementing layer diets with vegetable oils rich in polyunsaturated fatty acids does not change the nutritional composition of egg yolks. The supply of diets containing oils rich in polyunsaturated fatty acids does not reduce yolk cholesterol content.

\section{INTRODUCTION}

The enrichment of eggs with polyunsaturated fatty acids (PUFA), particularly with omega-3 fatty acids has attracted the attention of both researchers and the food industry, because these fatty acids are essential for normal body development and play an important role in the prevention of heart diseases, diabetes, arthritis, inflammatory and auto-immune conditions, and cancer (Simopoulos, 2000).

Most egg lipids are concentrated in the yolk, and consist of lipoproteins, phospholipids, triacylglycerols, and cholesterol. The lipid fraction of the yolk is composed of $8.7 \mathrm{~g}$ saturated fatty acids, $13.2 \mathrm{~g}$ monounsaturated fatty acids, $3.4 \mathrm{~g}$ polyunsaturated fatty acids and $1.120 \mathrm{mg}$ cholesterol per $100 \mathrm{~g}$ of fresh yolk (Holland et al., 1997).

Some researchers (Baucells et al., 2000; Grobas et al., 2001; Gómez, 2003; Mazalli et al., 2004) demonstrated the possibility of changing the fatty acid profile of the lipid fraction of eggs by reducing the dietary concentration of some fatty acids (lauric acid and short-chain saturated fatty acids) in exchange of long-chain fatty acids, such as eicosapentaenoic acid (EPA, C20:5n-3) and docosahexaenoic acid (DHA, C22:6n-3), which present more than 18 carbons in their chemical structure. 
Cholesterol deposition in the egg yolk can also be affected by nutrition (Hargis et al., 1991). The inclusion of specific feedstuffs in commercial layer diets, such as vegetable oils rich in unsaturated fatty acids used to change egg lipid profile and to reduce egg cholesterol content. Literature results on the possible effect of the diet on egg and blood cholesterol levels are contractor. According to Holland et al. (1980) and Mori (2001), the addition of PUFA-rich oils in in the diet reduces blood and egg cholesterol concentrations. However, other studies showed that yolk cholesterol content cannot be changed because it seems to be constant, independently of dietary factors (Bertechini, 2003).

This study aimed at evaluating the effects of the supplementation of rapeseed, soybean, and canola oil in commercial layer diets on yolk cholesterol levels and composition in terms of total solids, protein, lipids, and minerals.

Table 1 - Ingredients and calculated nutritional composition of the experimental diets.

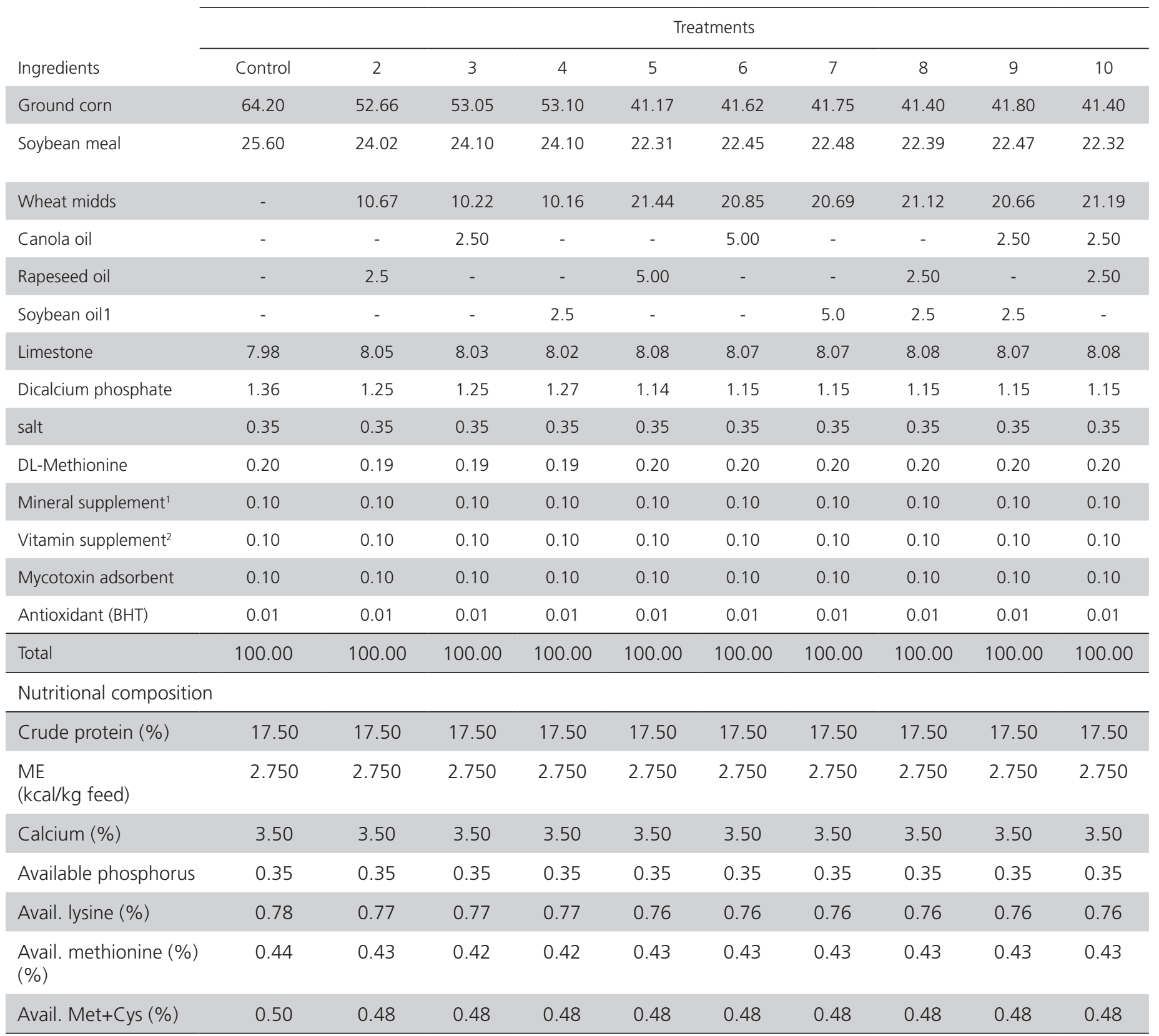

\footnotetext{
${ }^{1}$ Supplied per kg feed: copper: 8 mg; iron: 50 mg; manganese: 70 mg; zinc: 50 mg; iodine: 1.2 mg; selenium: 0.2 mg.

2 Supplied per kg feed: Vitamin A: 7.000 Ul; Vitamin D3: 2.000 Ul; Vitamin E: 5 mg; Vitamin K3: 1.6 mg; Vitamin B2: 3 mg; Vitamin B12: 8 mcg; Niacin: 20 mg: pantothenic acid: $5 \mathrm{mg}$; Antioxidant: $15 \mathrm{mg}$; vehicle QSP: $1 \mathrm{~g}$.
} 


\section{MATERIALS AND METHODS}

In this trial, 480 commercial white Lohman LSL layers, with 3 weeks of age at the beginning of the experiment, were fed for 112 days with diets supplemented with vegetable oils rich in polyunsaturated fatty acids, particularly in omega-3 and omega- 6 fatty acids, according to the following experimental treatments: Conventional feed with no oil addition (T1); inclusion of $2.5 \%$ rapeseed oil (T2); inclusion of $2.5 \%$ canola oil (T3); inclusion of $2.5 \%$ soybean oil (T4); inclusion of $5 \%$ rapeseed oil (T5); inclusion of $5 \%$ canola oil (T6); inclusion of $5 \%$ soybean oil (T7); inclusion of $2.5 \%$ rapeseed oil $+2.5 \%$ soybean oil (T8); inclusion $2.5 \%$ canola oil $+2.5 \%$ soybean oil (T9); and inclusion of $2.5 \%$ rapeseed oil $+2.5 \%$ canola oil (T10) .

Table 1 shows the ingredients and the calculated nutritional composition of the experimental diets.

Birds were housed in a brick house with 84 metal cages specific for egg production. Each cage was divided in two compartments with capacity of housing four birds each, housing a total of eight hens per cage. Independent feeders were placed in front of the cage, as well as nipple drinkers. A 17-h of light lighting program was adopted.

Feed intake and egg weight were weekly measured.

Yolk chemical composition (protein, total solids, lipid, and ash contents) and yolk cholesterol levels were determined on days 20,60, and 112 of the experimental period.

Yolk protein content was determined according to the micro-Kjeldahl method, n. 39.1.19, of the AOAC (2007) for total nitrogen determination. The methodology proposed by Silva \& Queiroz (2002) was applied to determine the percentage of total solids. Yolk ether extract content was determined according to the methodology described by the AOAC (2007), item 39.1.05. Ash content was determined according to the method described by Silva \& Queiroz (2002).

A completely randomized experimental design, with ten treatments with three replicates of six eggs each was applied.

The analyses to determine egg cholesterol content were carried out according to the methodology proposed by Bragagnolo \& Rodriguez-Amaya (2003) adapted as suggested by Mazalli et al. (2003), and cholesterol was determined using a commercial enzyme kit.

The option for using the enzymatic method for cholesterol determination was based on the work of Nogueira \& Bragagnolo (2002) and Mazzali et al.
(2003), who found that there were no cholesterol quantification differences between the enzymatic method, routinely used to determine serum cholesterol levels, and the chromatographic method, routinely used to determine cholesterol content in foods.

Data were submitted to analysis of variance of SAS statistical package (2000), and means were compared by the test of Tukey at 5\% significance level.

Yolk cholesterol was analyzed according to a completely randomized experimental design in a 10 x 3 factorial arrangement (10 treatment and three periods), with four replicates per treatment.

\section{RESULTS AND DISCUSSION}

Table 2 shows the fatty acid composition of the vegetable oils used in the experimental diets.

Table 2 - Analyzed fatty acid composition of the vegetable oils included in the experimental diets (\% of total fatty acids).

\begin{tabular}{lccc}
\hline & Canola oil & Rapeseed oil & Soybean oil \\
\hline Fatty acids & \multicolumn{3}{c}{$\%$} \\
\hline C16:0 - palmitic acid & 12.3751 & 6.3720 & 13.0608 \\
\hline C18:0 - stearic acid & 2.4502 & 3.9842 & 2.2366 \\
\hline C18:1 - oleic acid & 45.2735 & 24.8235 & 23.0449 \\
\hline C18:2 - linoleic acid $(\omega 6)$ & 36.5747 & 14.6624 & 56.4484 \\
C18:3 - linolenic acid $(\omega 6)$ & 3.3264 & 50.1580 & 5.2094 \\
\hline
\end{tabular}

Table 3 - feed intake (FI) and egg weight (EW) of white commercial layers fed diets containing different vegetable oils.

\begin{tabular}{lcc}
\hline & $\begin{array}{c}\mathrm{Fl} \\
\text { (g/hen/day) }\end{array}$ & $\begin{array}{c}\mathrm{EW} \\
(\mathrm{g})\end{array}$ \\
\hline Treatments & & \\
\hline Control & $120.35 \mathrm{c}$ & 64.13 \\
\hline $2.5 \%$ Rapeseed oil & $122.10 \mathrm{abc}$ & 64.91 \\
\hline $2.5 \%$ canola oil & $125.24 \mathrm{abc}$ & 64.04 \\
$2.5 \%$ soybean oil & $126.89 \mathrm{a}$ & 64.96 \\
$5 \%$ rapeseed oil & $123.03 \mathrm{abc}$ & 63.77 \\
\hline $5 \%$ canola oil & $123.14 \mathrm{abc}$ & 64.36 \\
\hline $5 \%$ soybean oil & $122.79 \mathrm{abc}$ & 65.10 \\
\hline $2.5 \%$ rapeseed oil $+2.5 \%$ soybean oil & $126.43 \mathrm{a}$ & 65.04 \\
\hline $2.5 \%$ canola oil $+2.5 \%$ soybean oil & $121.89 \mathrm{bc}$ & 65.35 \\
\hline $2.5 \%$ rapeseed oil $+2.5 \%$ canola oil & $121.08 \mathrm{c}$ & 64.70 \\
\hline Probability & $\mathrm{p} \leq 0.01$ & $\mathrm{p} \leq 0.05$ \\
\hline CV (\%) & 2.08 & 1.36 \\
\hline Means followed by different letters in the same column are statistically different by the & & \\
\hline test of Tukey ( $\leq 0.05)$ & & \\
\hline
\end{tabular}


Table 4 shows the yolk nutritional composition of the eggs of commercial layers fed diets containing different vegetable oils.

The analysis of variance indicated significant treatment effects on the lipid and mineral composition of the egg yolk, but there was no influence of treatments on yolk total solids and protein contents.

Seibel et al. (2005) did not find any differences in albumen or yolk protein content in the eggs of Japanese quails fed diets containing $2.7 \%$ fish oil or 5 and $10 \%$ of the solid fraction of fish chemical silage for 30 days.

The results obtained in the present study are consistent with the findings of Naber (1979), who asserted that egg protein characteristics are not influenced by the diet. Cobos et al. (1995), working with lipid supplementation of layer diets also did not find any differences in egg protein content.

Several authors reported the influence of diet on yolk vitamin (Surai \& Sparks, 2001), ashes (Cobos et al., 1995), and mineral (Manson et al., 1993) composition.

According to Naber (1979), the main egg component (lipids) may be easily changed by dietary manipulation. Hall \& Mckay (1993) found that egg lipid content is influenced by age in domestic fowl. According to Chwalibog (1992), as birds age, egg lipid content increases while protein content decreases.
The results obtained in the present study relative to yolk lipid percentage are consistent with those reported by Fennema (1993), who argues that variations in total yolk lipid content is more influenced by bird genetic strain than diet.

Sotelo \& Gonzáles (2000), analyzing the percentage composition of egg with low cholesterol levels, found that yolk lipid percentage varied between 29.37 and $30 \%$, which is consistent with the values obtained in the present study.

Relative to mineral composition, yolks from egg produced by hens fed the control treatment (no oil) were significantly different only from those derived from hens fed the diet supplemented with 2.5\% canola oil $+2.5 \%$ soybean oil, which present lower mineral content.

Yolk mineral content in the present study ranged between 1.76 and $2.05 \%$, which is consistent with the $1.92 \%$ determined by Sotelo \& Gonzáles (2000) when evaluating the composition of low-cholesterol eggs.

The obtained differences in yolk lipid and mineral contents may be attributed to individual differences inherent to each bird and tis metabolism than to the diet fed, as the yolk composition of eggs produced by layers supplemented or not with vegetable oils were similar. Therefore, it is unlikely that vegetable oil type may have influenced yolk mineral or lipid deposition.

Table 4 - Percentage composition in the fresh matter of total solids, proteins, lipids, and minerals in the egg yolk of commercial layers fed diets containing different vegetable oils.

\begin{tabular}{|c|c|c|c|c|}
\hline & $\begin{array}{c}\text { Total solids } \\
(\%)\end{array}$ & $\begin{array}{c}\text { Proteins (\%) } \\
\quad(\%)\end{array}$ & $\begin{array}{l}\text { Lipids } \\
(\%)\end{array}$ & $\begin{array}{c}\text { Minerals } \\
(\%)\end{array}$ \\
\hline \multicolumn{5}{|l|}{ Treatments } \\
\hline Control (no oil) & 51.49 & 16.99 & $30.14 a b$ & $2.05 b$ \\
\hline $2.5 \%$ rapeseed oil & 51.21 & 16.81 & $27.94 a$ & $2.05 b$ \\
\hline $2.5 \%$ canola oil & 51.20 & 17.07 & $32.21 b$ & $2.03 b$ \\
\hline $2.5 \%$ soybean oil & 51.29 & 16.82 & $29.45 a b$ & $1.96 a b$ \\
\hline $5 \%$ rapeseed oil & 51.54 & 17.18 & $27.93 a$ & $1.93 a b$ \\
\hline $5 \%$ canola oil & 51.31 & 16.69 & $27.63 a$ & $2.05 b$ \\
\hline $5 \%$ soybean oil & 51.03 & 16.88 & $29.75 a$ & $2.00 \mathrm{ab}$ \\
\hline $2.5 \%$ rapeseed oil $+2.5 \%$ soybean oil & 52.00 & 16.57 & $28.46 a$ & $1.91 \mathrm{ab}$ \\
\hline $2.5 \%$ canola oil $+2.5 \%$ soybean oil & 51.64 & 16.73 & $28.72 a$ & $1.76 a$ \\
\hline $2.5 \%$ rapeseed oil $+2.5 \%$ canola oil & 51.78 & 16.82 & $28.97 a$ & $1.81 \mathrm{ab}$ \\
\hline Probability & $p \leq 0.05$ & $p \leq 0.05$ & $p \leq 0.01$ & $p \leq 0.05$ \\
\hline CV $(\%)$ & 1.41 & 3.15 & 7.83 & 10.19 \\
\hline
\end{tabular}

Means followed by different letters in the same column are statistically different by the test of Tukey $(p \leq 0.05)$ 
There was a significant interaction between treatments and periods relative to yolk cholesterol content, as shown in Tables 5 and 6.

Table 5 - Yolk cholesterol content $(\mathrm{mg} / 100 \mathrm{~g})$ of the eggs of commercial layers fed diets containing different vegetable oils.

\begin{tabular}{lc}
\hline Treatments & Cholesterol $(\mathrm{mg} / 100 \mathrm{~g})$ \\
\hline Control (no oil) & 1078.81 \\
\hline $2.5 \%$ rapeseed oil & 1049.83 \\
\hline $2.5 \%$ canola oil & 1023.41 \\
\hline $2.5 \%$ soybean oil & 1066.43 \\
\hline $5 \%$ rapeseed oil & 1114.11 \\
\hline $5 \%$ canola oil & 1138.12 \\
\hline $5 \%$ soybean oil & 1096.14 \\
\hline $2.5 \%$ rapeseed oil $+2.5 \%$ soybean oil & 1090.15 \\
\hline $2.5 \%$ canola oil $+2.5 \%$ soybean oil & 1055.68 \\
\hline $2.5 \%$ rapeseed oil $+2.5 \%$ canola oil & 987.53 \\
\hline Probability & $p \leq 0.01$ \\
\hline Period & \\
\hline 20 & 792.04 \\
\hline 60 & 1356.56 \\
\hline 112 & 1061.47 \\
\hline Probability & $p \leq 0.01$ \\
\hline Treatment $x$ Period & $p \leq 0.01$ \\
\hline CV $\%)$ & 8.74 \\
\hline
\end{tabular}

There was a significant interaction between treatment and period for yolk cholesterol content in eggs from layers submitted to all experimental treatments. The highest cholesterol levels in the egg yolk of layers fed the diet with no oil were obtained on days 60 and 112 of the experimental period.

Egg yolks produced by layer fed oils presented lower cholesterol levels after 20 days of inclusion in the experimental diets; however, on day 60 , cholesterol levels increased, and were intermediate compared with those recorded on day 112 of the experimental period. It was observed that egg cholesterol content tended to increase as birds aged. These results are consistent with those reported by Beyer \& Jensen (1989), who asserted that egg cholesterol level is positively correlated with bird genetics and age, egg weight and yolk weight, and negatively correlated with lay percentage and dietary protein levels.

The high yolk cholesterol content in the eggs of hens fed $5 \%$ vegetable oil may be explained by the study of Vargas \& Naber (1984), who correlated yolk cholesterol content with dietary energy balance and argued that excessive energy intake, beyond maintenance and production requirements, increases body weight and cholesterol synthesis. Therefore, excessive cholesterol would be transferred to the egg yolk.

Studies on layer dietary manipulation to reduce egg cholesterol content have shown conflicting results. Some report that the polyunsaturated fatty acids that compose the vegetable oils supplemented in the diet reduce both egg and blood cholesterol levels (Harris \& Wilcox, 1963; Holland et al., 1980; Mori et al., 1999). On the other hand, these results were not obtained by other authors (Bartov et al., 1971; Wasburn \& Nix, 1974), or in the present study.

Santos (1998) found that the addition of soybean (2 and 4\%), canola (2 and 4\%), or polyunsaturated marine ( 0.1 and $0.2 \%)$ to the diet of commercial layers did not affect egg yolk cholesterol levels.

Table 6 - Details of the interaction between periods of experimental diet supply and experimental treatments relative to yolk cholesterol content of the eggs of commercial layers fed diets containing different vegetable oils.

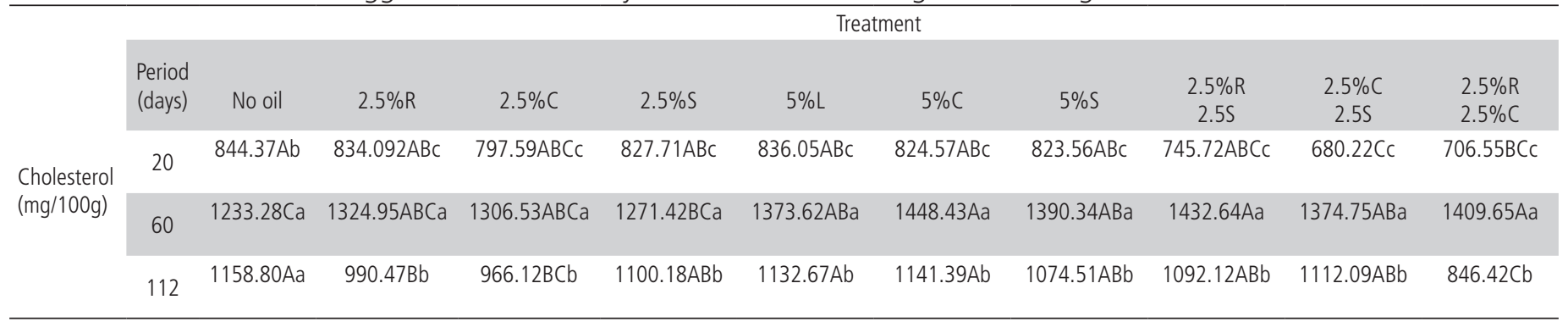


Consistent results were obtained by Grobas et al. (1997), who did not observe any differences in egg cholesterol control when comparing a wheat- and soybean-based diet with no fat supplementation (control) with the same diet supplemented with 7.5\% tallow, olive oil, soybean oil, rapeseed oil, or fish oil.

According to Bertechini (2003), the chicken is capable of producing 10 times more cholesterol per $\mathrm{kg}$ of liver than humans. Therefore, manipulating layer diets to reduce egg cholesterol levels is not very effective, as chickens are able to maintain the egg cholesterol levels that are considered essential for egg composition, as observed in the present study.

Yolk cholesterol concentration is very resistant to changes because there is a required yolk cholesterol level to ensure embryo development (Shafey \& Cham, 1994). However, hens are able to change yolk polyunsaturated fatty acid content in response to dietary lipid source. The reason is that, as opposite to mammals, poultry absorb dietary fat through the portal system as portomicrons, which are directly absorbed into the blood and transported to the liver, the main lipogenesis location, thereby allowing direct fat absorption by the liver (Van-Elswyk et al., 1994).

\section{ACKNOWLEDGEMENTS}

The authors thank FAPESP for the research grant and $L A B O R L A B$ for donating the enzyme kits.

\section{CONCLUSIONS}

Based on the obtained results, it is concluded that the supplementation of different vegetable oils to commercial white layer diets does not change egg nutritional composition (total solids, protein, lipids, and minerals).

The supply of diets containing oils rich in polyunsaturated fatty acids does not reduce yolk cholesterol content. However, egg cholesterol content tends to increase as birds age.

\section{REFERENCES}

Association of Official Analytical Chemists. Official methods of analysis. 18th ed. Maryland: Current through Revision 2; 2007.

Bartov I, Bornstein S, Budwoski P. Variability of cholesterol concentration in plasma and egg yolks of hens and evaluation of the effect of some dietary oils. Poultry Science 1971;50:1357-64

Baucells MD, Crespo N, Barroeta AC, López-Ferrer S, Grashorn MA. Incorporation of different polyunsaturated fatty acids into eggs. Poultry Science 2000;79:51-59.
Bertechini AG. Mitos e verdades sobre o ovo de consumo. 21 th Conferência de Ciência e Tecnologia Avícola; 2003; Santos, São Paulo. Brasil. p.19.

Beyer RS, Jensen LS. Overestimation of the cholesterol content of eggs Journal of Agriculture and Food Chemistry 1989;37:917-20.

Bragagnolo N, Rodriguez-Amaya DB. Comparison of the cholesterol content of brazilian chicken and quail eggs. Journal Food Composition Analysis 2003;(16)2:147-153

Chwalibog A. Factorial estimation of energy requeriment for egg production. Poultry Science, 1992;71:509-515.

Cobos A, Hoz L, Cambero Ml, Ordóñez JA. Dietary modification and hen strain dependence of egg yolk lipids. Food Research International 1995;28:71-76.

Fennema OR. Química de los alimentos, Zaragoza: Acribia; 1993.

Gómez MEDB. Modulação da composição de ácidos graxos poliinsaturados ômega 3 de ovos e tecidos de galinhas poedeiras, através da dieta. I. Estabilidade oxidativa [tese]. São Paulo (SP): Universidade de São Paulo; 2003

Grobas S, Mendes J, Medel P, Lazaro R, Mateos GG. Influence of energy, linoleic acid and fat content of the diet on performance and weight of egg components of brown layers. Poultry Science 1997;76:256.

Grobas S. et al. Influence of source and percentage of fat added to diet on performance and fatty acid composition of egg yolk of two strains of laying hens. Poultry Science 2001;80:1171-79.

Hall LM, Mckay JC. The relationship between yolk cholesterol and total lipid concentration throughout the first year of egg production in the domestic fowl. Poultry Science 1993;34: 487-95

Hargis PS, Van Elswyk ME, Hargis BM. Dietary modification of yolk lipid with savelha oil. Poultry Science 1991;70:874-83.

Harris PC, Wilcox FH. Studies on egg cholesterol: 1. Genetic variation and some phenotypic correlations in a random bred population. Poultry Science 1963;42:186-89.

Holland KG, Grunder AA, Williams CL. Response to five generations of selection for blood cholesterol levels in White Leghorns. Poultry Science 1980;59:1316-26

Holland B, Welch AA, Unwin ID, Buss DH, Paul AA, Southgate DAT. The composition of foods. 5th ed. Cambridge: Redwood Books; 1997.

Manson JM, Picken KJ, Draper MH, Thompson R. Variation among individual white-leghorn hens in the concentration of minerals in the albumen and yolk content of their eggs. Britsh Poultry Science 1993;34:899909

Mazalli MR, Saldanha T, Bragagnolo N. Determinação de colesterol em ovos: comparação entre um método enzimático e um método por cromatografia líquida de alta eficiência. Revista Instituto Adolfo Lutz 2003;62(1):49-54

Mazalli MR. A comparison of the feeding value of different sources of fats for laying hens: 2. Lipid, cholesterol and vitamin E profiles of egg yolk. Journal Applied Poultry Research 2004;13:280-290.

Mori AV, Mendonça CX, Santos COF. Effect of dietary lipid lowering-drugs upon plasma lipids and eggyolk cholesterol levels of laying hens. Journal of Agriculture and Food Science 1999;47:4731-35.

Mori AV. Utilização de óleo de peixe e linhaça na ração como fontes de ácidos graxos poliinsaturados ômega 3 em ovos [tese]. São Paulo (SP): Universidade de São Paulo; 2001. 
Murata LS, Ariki J, Machado CR, et al. Effect of oils sources on blood lipid parameters of commercial laying hens. Brazilian Journal of Poultry Science 2003;5(3):203-206.

Naber EC. The effect of nutrition on the composition of eggs. Poultry Science 1979;58: 518-28.

Nogueira GC, Bragagnolo N. Assessment of methodology for the enzymatic assay of cholesterol in egg noodles. Food Chemistry 2002;79:267-70.

Santos COF. Efeito da adição de óleos poliinsaturados à ração nos níveis de lipídios plasmáticos e de colesterol no ovo de galinhas poedeiras [dissertação]. São Paulo (SP): Universidade de São Paulo; 1998.

SAS Learning Edition. Getting Started with the SAS Learning Edition, Care. North Carolina: SAS Institut; 2000.

Seibel NF, Barbosa LN, Gonçalves PM, Souza-Soares LA. Qualidade física e química de ovos de codornas alimentadas com dietas modificadas. Revista Instituto Adolfo Lutz 2005;64(1):58-64.

Silva DJ, Queiroz AC. Análise de alimentos: métodos químicos e biológicos.3 ed. Viçosa: UFV; 2002.

Shafey TM, Cham BE. Altering fatty acid and cholesterol contentes of eggs for human comsuption. In: Sim JS, Nakai S. Egg uses and processing technologies: new developmentes. Washington: CAB International; 1994. p. $374-85$

Simopoulos AP. Role of poultry products in enriching the human diet with n-3 PUFA. Human requirement for n-3 polyunsaturated fatty acids. Poultry Science 2000;79:961-70.

Sotelo A, González L. Huevo em polvo con bajo contenido de colesterol. Características nutricias y sanitarias del producto. Archivos Latinoamericanos de Nutrición 2000; 50:134-41.

Surai PF, Sparks NHC. Designer eggs: from improvement of egg composition to functional food. Trends in Food Science \& Technology 2001;12:7-16.

Van-Elswky ME, Hargis BM, Willians JD, Hargis PS. Dietary menhaden oil contributes to hepatic lipidosis in laying hens. Poultty Science 1994;73(5):653-62.

Vargas R, Naber E. Relationship between dietary fiber and nutrient density and its effect on energy balance, egg yolk cholesterol and hen performance. Journal of Nutrition 1984;114:645-52.

Wasburn KW, Nix DF. Genetic basis of yolk cholesterol content. Poultry Science 1974;53:109-15. 